\title{
Thinking of moving overseas? Reflections from a social worker's journey of migration to New Zealand
}

\section{Helen Barker Troughton}

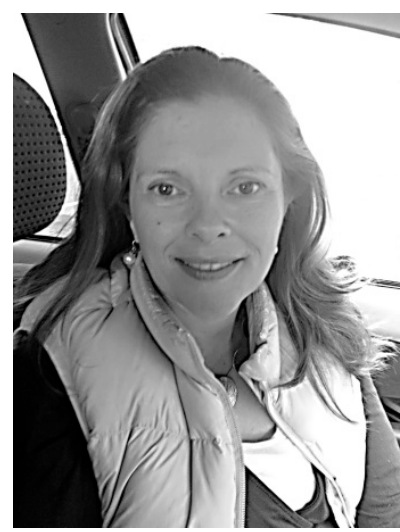

Helen works in the Bay of Plenty, in education and medical social work. She was inspired toward social work after visiting the slums in Delhi. She has experience in relief and development with Tearfund (UK), older persons and young people. She enjoys outdoor activities and fun with friends and family.

\section{Abstract}

This is one woman's story of living through times of significant change. These changes include migration overseas and entering the part-time workforce after becoming a mother in later life. It describes the surfacing of personal questions, self-reflections and actions she found helpful as she used the new experiences to reshape her identity and become more effective personally and as a social worker. Through these times she realised a desire to live more meaningfully in the midst of change, loss and uncertainty. She looks at the nature of resilience and how this can be harnessed to become stronger at home and at work. She shares her personal journey to offer hope to herself and others on a similar journey, including suggestions of ways to embrace change. The main voice is the migrant asking questions and pointing toward snippets of light she hopes will help others.

\section{Approach}

The piece is written in an autoethnographic style after Ellis (2011). Autoethnography uses aspects of autobiography and ethnography; it is, 'an approach ... that seeks to describe and systematically analyse personal experience in order to understand cultural experience.' (Ellis, Adams, Bochner, 2010). This is a narrative piece, using critical reflection to look at perceptions and social behaviours.

\section{How did I get here?}

The neat packing boxes I had constructed to contain my belongings were filled to capacity, stretched and out of shape, landing with a thud on New Zealand soil; it felt like a metaphor for my life. It was 2010, autumn in my world and spring in my new one. I had just moved from London, England to New Zealand; inside me, too, my world was turning upside down.

The move was neither forced nor entirely voluntary. It happened quickly whilst on maternity leave after both my job and my partner's job were threatened during the global economic downturn. We had few work options and decided to take the offer of a job near 
to his family. The move held significant gains and losses; it was a beautiful environment (the Bay of Plenty) where we had lots of space to breathe and to explore. On the other hand, I had left behind my treasures, friends and family. Somewhere very near the surface I felt a dripping ache of irony, every time I heard the nonchalant Kiwi expression, 'Oh, you've shifted'.

I grappled with my identity, asking myself many questions 'What does it mean to be 'me' in this environment, a new migrant, a new mum, new 'in-law', new to the part-time job-seeker scene?' I wondered what options existed. I tried hard to find the switch to 'return to normal' but I could not find it. I began sifting through my 'stuff' - my belongings as well as my internal baggage - with the dawning realisation that I must gather only what I could carry, purely what would be helpful for this different life on this side of the planet. A journey of many-facetted change had begun.

\section{Trying to get a foothold}

Looking back, I interpret the changes with the help of reflection and curiosity. At the time though, the process felt bumpy and I did not want to change myself so radically or so quickly. My mind's ability for self-talk seemed almost without bounds, I generated questions incessantly trying to make sense of my new situation. Looking back, I relate to Covey's (1997) encouragement to develop ourselves when we have the chances 'to choose' and 'to act'. Covey talks about four unique gifts: self-awareness, conscience, imagination and independent will (pp. 37-38). He highlights, 'The essence of proactivity and the use of these four unique gifts, lies in taking the responsibility and the initiative to focus on the things in our lives we can actually do something about.' I was acutely aware of my shortfalls, I knew I needed to choose good attitudes. Covey talks about operating within our Circle of Concern and Circle of Influence (pp. 40-44). The Circle of Concern incorporates all things we may be concerned about in our life; the Circle of Influence sits within this, but incorporates those things we can genuinely do something about. 'The reactive tendency is to focus on the Circle of Concern, but this only causes the inner Circle of Influence to be diminished... but proactive people focus on their Circle of Influence. As a result, that circle increases.' (p. 41). I wanted to be more proactive and to feel I had more control over what happened to me - after all, didn't my circumstances present many 'opportunities for growth'?

\section{Keeping the main thing the main thing}

I had been going through adjustments already, hadn't we all? A new mum at 40, grappling with the turnabout of days and nights, my questions pinged around my mind like balls around a pin-ball machine: 'How much should I orientate myself toward my child, myself or others?', 'If family is the most important consideration, what does that mean for my work, the things I've been concentrating on over previous years?', 'How do I make sense of work outside of the home?', 'Why doesn't our society value the things done inside the home, building a place of safety where family and friends grow?'

I knew I needed to put first things first, and I asked myself, 'What on earth does that look like now that I have lost my social diary, my work tasks and my sense of being known?' I wanted to shape my identity, to feel significant again, 'How would that be as my daily achievements are not seen by others?' , 'Am I dependent upon others for validation?' 
I wanted to be a good daughter, 'How could I be committed to caring for ageing parents when I had moved to the far side of their world?' I wanted to be a good friend, and have good friends; I attempted to navigate the elusive, tiny windows of time between the days and nights of the hemispheres. I soon realised that either I or they would have to be up so early or so late that we couldn't reasonably function as parents - these thin ends of the days and nights were huge blockages to connections. I wished the sun would stop moving, that time would stand still just long enough for me to connect with 'my people', I felt powerless.

Social work often attracts people with some kind of history of struggle; I would need to press in to find a way forward. I ached with longing to adapt swiftly, to deliberately shape my world. With my imaginary long-bow I even hoped for joyfulness, and I questioned how I would find the inner resources to pull the bowstring as far back as I needed to stretch it.

\section{Identity in a new place}

I needed to develop some kind of a 'fit' here, though I felt fragmented. Sanchez (2010) talks about the formation of identity and 'the individual and collective location in space and time' (p. 73). She believes that identity formation has been threatened as social structures have been weakened, leading to a 'breakdown of identity referents' (p. 71). She questions, 'How are these tensions and divisions having an impact on the orientation and sense of personal and collective existence, and on the capacity to make sense of experiences?' (p. 73).

I did feel like an alien in many 'worlds', classed as a 'young mum' because of the age of my baby, yet clearly not a 'young' mum in my fourth decade! My new role meant a loss of control, independence, choice and the move exacerbated this. I had revelled in my friends and networks in London, I loved being around people who made things happen on the global stage. Here, life felt quiet and still. New Zealand had few people, resources felt scarce. The pace was slow, systems unfamiliar; I felt different and intensely vulnerable, separated from my supports. I missed having a diary full of events to interpret as significance. As Lucado (2005) says, 'No one knows me, we think. People know my name, but not my heart. They know my face, but not my feelings.' (p. 64).

\section{Life in orbit}

Especially during the first few weeks and months, my consciousness was heightened. I found myself 'watching' what I was thinking, doing, saying. I reflected constantly, seeking to make sense of my life in New Zealand. I wondered how early settlers had navigated through migration. I came across a book, Brave Days - Pioneer Women of New Zealand compiled by The Women's Division of the New Zealand Farmer's Union (WDNZFU); it describes 'Delving into the history of New Zealand's pioneers reveals as an outstanding factor the quality of those women who triumphed over isolation, privations, danger and almost insurmountable difficulties, turning these all into a glorious adventure...' (1939, p. 15). I had had relative ease by comparison, but I felt my inner resources challenged.

The WDNZFU (1939) presents early settlers almost victoriously:

... the pleasure of triumphing over obstacles, the satisfaction in the development of hitherto unsuspected qualities of courage and resource - these were compensations which led them onward, however rough and hard the road (pp. 15-16). 
Although this period was arguably 'the height of 'pioneer worship' in New Zealand' (Phillips, 2012), I could tell they had risen to significant challenges. Maybe I had been spoilt by plenty in England:

One wonders in the present scramble for ease and pleasure, and security without individual effort, whether something of zest has not gone out of life... some spur of necessity, some testing of strength and courage is needed to bring out the deeps of character, whose richness and quality may otherwise lie unsuspected and unrevealed (p. 16).

I needed to shift my perceptions, to find new thoughts. I would need to stare in to my own reflection and be honest with what was mirrored back. I would also need to be kind to myself, to see what I could do well, a little like Appreciative Inquiry. According to Cooperrider (2011), a leading consultant on Appreciative Inquiry (AI), 'It is imperative to have an eye that can appreciate, an eye that can see, and surface the true, the good, the better, the possible, everything that brings asset and strength to a system.' I liked this outlook; AI 'moves us away from 'What problems are you having?' and toward 'What is working around here?' (Fiorentino, 2012).

'What ingredients would I need?' I wondered. Ortberg (2002) talks about our human need to change, to grow: 'The possibility of transformation is the essence of hope.' (p. 20). He believes 'The desire for transformation lies deep in every human heart. This is why people enter therapy, join health clubs, get into recovery groups, read self-help books, attend motivational seminars and make New Year's resolutions.' (p. 20). Yes, this was what I wanted! How could I navigate through the pain?

Cloud and Townsend (2001) talk about the process of growing in who we are, in our character through pain; we cannot step over it to avoid it but we must go through it and actually feel the pain. As I look back over these times of transition, I relate to their words:

We all have coping mechanisms that cover up pain, help us deal with fear, cope with relationship inabilities, and help us hold it all together. Trials and suffering push those mechanisms past the breaking point so we find out where we need to grow. Then true spiritual growth begins at deeper levels, and we are healed. Righteousness and character take the place of coping (p. 213).

I find something deeply comforting here. For me, my need to 'feel the pain and keep going forward', is an on-going piece of work.

\section{Coming out of the woods}

My day-to-day world was small, having shrunk to the micro-environment of tiny, repetitive tasks of life at home with a small child. This was the season for now and I needed to become more adaptive, flexible, resilient, and more thankful each day. These sounded like familiar terms from social work and I was acutely aware that I had just the same needs as others - whether service users or social workers. My last piece of work had been teaching healthy choices to young people; I recalled the well-trodden phrases that characterised our team: 'You are unique, you are worth good choices, when you fall down get back up again and make one more good choice, spend time with people who genuinely love you.' (Your Choice, 2009). I could quite easily tell others how important this was, but how easily would I embrace it now, for myself? 


\section{Mapping out the landscape in this new place}

I had always been fascinated by what goes on beneath the surface. I started asking questions to explore 'How did things work in New Zealand - who made decisions about how resources were allocated?', 'Who holds power?', 'How much priority is given to people living in poverty and disadvantage?' I noticed many older people around me (of course, it's a warm beautiful place by the sea), but how could the country afford costs of care? Jobs were scarce, work of 'decent' wages was scarcer still. If I wanted to work, I would need to be highly intentional, to seek very actively, to work hard to forge my own path. Somehow I felt spurred onward, perhaps I was taking on elements of iconic Kiwi attributes - ingenuity, independence, hard work.

Perhaps this was not so much a devastating change, but an opportunity to be transformed. Had I not encouraged clients to embrace change and to fall forward into their 'new normal'?! Had I not read that the Chinese symbol for 'crisis' involved danger and opportunity? (Canda and Furman, 2010, emphasis my own).

Magruder Watkins, Mohr and Kelly (2011) highlight the times we are in and the need for understanding what is happening in human services:

We live in a time unimaginable, even to our parents' generation - a time of rapid and continuous shifts in how human beings experience, describe and interact with the world around us. This macro shift calls for new levels of knowledge and a higher capacity to understand and live in an environment that is no longer experienced as stable, predictable or even comprehensible (pp. 1-2).

I felt as if I was cutting my own track through it all, and I wondered, 'There must be literally millions of people living these kind of changes, where are they, how do I hear their voices?'

In my late teens, I had worked on a refugee camp and I now found myself re-visiting my time there, remembering the expressions on the faces of those I'd come to call friends displaced, uncertain. I recalled stories which helped them make sense of their journey; I was the foreigner now. I yearned to be known, to laugh about myself with someone who knew me, to feel that my precious things were going to be valued. I fought with myself internally, my own resistance to change and to flexing.

\section{What's in our control, what's not? Being small in a big world}

In The Social Work Podcast, Singer (2010) talks about his own time of living overseas; he conveys the paradigm shifts he went through, being confronted with different assumptions about how to behave. He says of his time overseas that it 'taught me that my world was small; the world was very, very large.' For me, I wanted to become more knowledgeable about the players that held power over my world, I wanted to understand more about global politics and economics, things that had rippled-down the changes we had experienced.

The suddenness of the move prompted questions - 'How much control do I actually have?', 'Could we have seen the changes sooner, been more prepared?' , 'Did we have significant blind spots (individually or as a couple) that meant we had made such a big transition, quickly?' We had needed work that paid enough to support us; my social work role did not. 
I questioned the implications of having a social work career, where it's more about calling than money: 'Was it actually a luxury to be in a helping profession whose wages struggled to provide for a family?', 'How could my partner and I go after meaningful work as well as have a sense of control over where we live?', 'How come living costs are so high in New Zealand, wages half the UK's, social work registration about 11 times, flights back almost twice the price?' (One English friend said she felt 'trapped', too skint to go back.)

When I went to the depot to arrange delivery of our shipping container, I was surprised when the man in charge asked if we were moving out, to Australia, 'like everyone else'. I realised that in his eyes at least, we were taking an unusual step by moving to New Zealand. My internal dialogue was running riot, 'Help! How on earth had I come to this point of so little control over my life?', 'I'm slipping off the ladder... what can I do about it?', 'Does the ladder even matter or is there a more meaningful one and could I discover it here?'! I wanted to stop thinking so hard, a well-meaning person suggested I just go out for a coffee, but my questions got louder: 'Oh no, is thinking about these things considered a problem here?', 'Is 'not thinking so hard' a denial response and is that denial the reason for so many coffee shops here?!' I had to laugh at myself!

\section{Status anxiety}

I did not like to admit this ugly fear, 'Status Anxiety' (de Botton, 2005), but I think something of this was going on. De Botton says it is the worry that we might be currently occupying too modest a rung or are about to fall to a lower one. It relates to wanting to keep ourselves connected to modern day expectations of material progression:

The anxiety is provoked by, among other events, recession... it is because our self-conception is so dependent upon what others make of us ... we may fail due to stupidity or an absence of self-knowledge, macro-economics or malevolence (pp. 4-5).

I had so much growing to do.

\section{Practical steps}

'What could I do, practically, to help myself make a space where I could be and belong?' I wanted to learn the boundaries of social work practice in this new place. I searched for what looked like a safe environment and was thankful to find locum work in the local hospital. From a practice point of view, I soon learned there was more time for people, freedom to use my initiative. The empowerment that afforded me meant I could empower patients.

I was part-time, which felt like putting on a strange-fitting jersey to me, but I felt reassured to be amongst a team of other professionals and I was so grateful for their kindness. As a part-timer I had drop-offs and pick-ups to bear in mind and a lurching feeling that I now needed to orientate myself toward leaving work at a certain time rather than staying until I had fully achieved what I wanted to (which I had done previously through my single years). However, I was not encumbered by form-filling here and I enjoyed practising. It was a breath of fresh air, reflected in the outside environment. I drank-in the warm sea air under a huge expanse of blue sky. There was something solid, straightforward and securing about Aotearoa New Zealand - the land of the long white cloud. 
I took a home-study course called Mauri Ora (cultural identity), about the land, history and culture of Māori. I discovered that the lens of biculturalism meant there were two statuses of people here - Tangata Whenua, 'the people of the land' (Māori) and Tangata Tiriti 'the people of the Treaty' (of Waitangi, non- Māori); this gave the right for non-Māori to dwell in the land. These aspects helped me contextualise this land and its people, which engendered confidence in my own presence here in Aotearoa New Zealand.

I discovered that there were two social work bodies, the professional Aotearoa New Zealand Association of Social Workers (ANZASW), run for and by its members to support and guide practitioners, and the Social Work Registration Board (SWRB), a government agency overseeing registration (which is not yet compulsory for all social workers, but is mandatory for educators). Gaining my registration was a process of competency assessment, including a paper-based assessment and 2,000 hours of practice in-country. It was a robust exercise and I was grateful that my work at the hospital would achieve this.

\section{Resilience}

During all of these times, resilience had taken on greater meaning for me, I wanted more of it! Clinton (2008), a psychiatrist and researcher, conveys the strength in resilience as:

...being transformed and altered by an experience of adversity so that one is not the same: the person with resilience does not return to a former state of functioning, but is actually better off. Resilience describes individuals who do not simply cope, but recover in a way that demonstrates they are moving on with life in a thoroughly positive way (p. 216).

When I see resilience in others it looks attractive and holds a sense of great worth. For that though I could see I had to pay a price, it can only be developed through adversity:

Resilience refers to doing well, despite adversity... People who demonstrate resilience are those who thrive in the face of trouble ... resilience requires that someone both be exposed to an adverse event or conditions and demonstrate an outcome in which that person does better than would have been expected (Clinton, 2008, p. 214).

One of the challenges for me was to let go of things I was holding on to, weights that were too heavy, losses through the moving experience, my own sense of wanting to have more control over life events than I had. I could easily have been drawn into prolonged mourning, but I could not afford that, I had to work hard, believe that my strength would come at each point it was needed. Reading the Bible, I heard 'Be strong and courageous. Do not be frightened, and do not be dismayed, for the Lord your God is with you wherever you go.' (Joshua 1:9, ESV).

\section{Searching for the positives}

Asking myself 'Is moving overseas good for us?' , 'Is significant change good for us?' I believe that moving overseas certainly helped to shape my personal and professional self, though I feel sure there are less drastic methods and maybe it's best to grab the learning that's all around us first of all! Singer (2010) talks about the benefits of a social worker moving overseas; he sees the process of learning that accompanies the move to enhance the worker's quality of work, their adaptability, flexibility and confidence to deal with new or unusual situations. 
On my good days, I see it as a privilege to be in a process that enables me the opportunity to learn new ways and I am grateful for the chance to explore what I can become. On my harder days, I struggle with flexing, of choosing positive attitudes in each new situation. I battle with myself and my limitations, just as I probably would in my own country.

Clinton (2008) talks about the importance of support and of hope, that those with resilience have people 'who believe in them and who will help them develop internal strengths and the capabilities to cope, develop competence and hope' (p. 221). Wow, if I could be more hopeful then that's got to help me and those around me, family as well as clients; I would consider that to be one of the greatest assets, after all, 'Hope is perhaps the greatest internal characteristic of resilience' (p. 221).

The importance of learning to ask for help is also a characteristic which Clinton (2008) believes to be integral to resilience. I was unknown here, so each friendship was pretty much without strings, I could easily be open, transparent and vulnerable. That came with an energy, creativity, new ways to approach situations and confidence. Brown (2011) speaks widely on this topic, portraying how crucial it is to have vulnerability; overcoming our own shame in order to have an attitude where we have nothing to lose, we readily admit our shortcomings and are not trying to show ourselves as all-capable.

\section{Relevance to social workers}

I ask myself, 'Can we have more insight, more emotional intelligence?' I feel sure most of us would want that! Grant and Kinman (2012) highlight significant elements:

Emotional intelligence was one of the strongest predictors of resilience in social work students, suggesting that effective emotion management skills are likely to help social workers withstand the stressful nature of the job (p. 610).

They highlight these, to enhance emotional intelligence and resilience:

- Mindfulness;

- Thinking skills (Cognitive Behavioural Techniques);

- Peer coaching to enhance social support and promote wellbeing;

- Self-awareness and action planning; and

- Utilising supervision for reflective practice' (p. 612).

Very much related to these is self-monitoring; this is one of the skills that I found myself using a lot through the whole process of transition. Writing this piece using autoethnography helps me in the process of self-monitoring. Self-monitoring was looked at by Epstein, Siegel and Silberman (2008). They found that practitioners (in their case medical) could improve self-monitoring, to engage in their practice more fully. Their research drew upon cognitive neuroscience and the brain functions related to self-monitoring, with 'the structural and functional changes that occur during mental training to improve attentiveness, curiosity and presence' (abstract). They offer 'lessons for practice' including:

- Self-monitoring depends on the ability to regulate attentions, maintain curiosity, and be flexible during daily work, especially when under stress and multitasking. 
- Self-deception, denial, and delusion are common barriers to self-assessment and self-monitoring.

- Self-monitoring can be improved by cultivating the 'observing self': adopting a 'beginner's mind', seeing 'facts' as conditional, considering multiple perspectives, suspending categorization and judgement, and developing habits of self-questioning (p. 12).

\section{Offerings for others going through change}

Through the changes I now look back and see the difference between the 'me' then and the 'me' now. Now, I am 'mama' to two sons and I have developed a space for myself through work. I have evolved my work focus to train people who want to become people helpers, including social workers. My questions are more frequently around what I can contribute, for example 'What can I do to pass on my learnings and help others in their learning journeys?' My focus is to give what I have, where there is a need. So far, I offer these learnings:

- To 'make friends with change' when one can, as it is one of the constants in life!

- Thus, to be flexible, adaptive, and ready for change - it's probably coming!

- To hold hope

- To develop resilience

- To know what is within one's control and what is not

- To have one's eyes wide-open

- To have faith, knowing that one does not see all, but more light will come with the walk forward

- To see one's life as part of something bigger than oneself

- To let go, hold lightly, go with the skid (see below, Carrington, 2002)

- To connect with others, be part of a supportive group

- To do fun activities

- To laugh often

- To practise thankfulness.

\section{Reflections}

Perhaps I have become a bit better at letting go. I do not need to hold onto things that hold no currency here, even if I had been carrying them for a long time. Carrington (2002) in her book The Power of Letting Go conveys that, '....we can sometimes respond to a problem by shedding our rigid ways of behaving so that we can handle the matter and go on from there' (p. 4). Learning to let go has helped me recognise I have power over my perceptions and how I responded to situations. I have not had extra capacity to carry unnecessary burdens of any sort, rather responsibilities to myself and my family and I needed to find a way to make it. I have 'shifted' internally. As Carrington (2002) says, 'The situation and the people around you are unchanged ... You now see, hear and experience your surroundings differently. Your perception is all that had to change for you to become more effective' (p. 4). I love the way she likens it to a driver in a skid, instead of fighting against it, going with the skid - 'Releasing encourages us to go with the problem to regain our emotional balance' (p. 5).

I have learned to look for the good things and to value those. I am getting used to the kinder rhythm of life. I have become better at appreciating friendliness of people in day-today life, with less crowded spaces and time, where many people are more generous with 
their time; it feels as if the environment is kinder so we can be kinder to one another. I have learned to embrace the bounds of outside living, I am more in touch with my physical self. I enjoy feeling alive around fresh expanses of sea and sky, the ease of reaching a beautiful bay or snowy mountain and often having it to ourselves. I know that if I want to sleep under the dreamy expanse of southern starry skies, I need to flex, to adapt and work hard to create a space where I fit and flourish.

\section{References}

Brown, B. (2011) The power of vulnerability. TEDTalks on Youtube. Retrieved 2nd October 2013 from http:/ / www. youtube.com/watch? $\mathrm{v}=\mathrm{iCvmsMzlF7o.}$

Canda, E. R., \& Furman L. D. (2010). Spiritual diversity in social work practice: The heart of helping (2nd ed). New York, New York: Oxford University Press.

Carrington, P. (2002) The power of letting go: A practical approach to releasing the pressures in your life. London, England: Vega.

Clinton, J. (2008). Resilience and recovery. International Journal of Children's Spirituality, 13(3), $213-222$.

Cloud, H., \& Townsend, H. (2001). How people grow: What the Bible reveals about personal growth. Sydney, Australia: Strand Publishing.

Cooperrider, D. (2011). Appreciative inquiry: A conversation with David Cooperrider. The Drucker School on Youtube. Retrieved 10th March 2013 from http: / / www.youtube.com/watch?v=3JDfr6KGV-k.

Covey, S. (1997). The 7 habits of highly successful families. New York, New York: Golden Books Publishing.

De Botton, A. (2005). Status anxiety. London, England: Penguin Books.

Ellis, C. S. (2011). Jumping on and off the runaway train of success: Stress and committed intensity in an academic life. Symbolic Interaction, 34(2), 158-172.

Ellis, C., Adams, T. E., \& Bochner, A. P. (2010). Autoethnography: An overview. Forum Qualitative Sozialforschung / Forum: Qualitative Social Research, 12(1), Art. 10, http:/ / nbn-resolving.de/ urn:nbn:de:0114-fqs1101108.

Epstein, R. M., Siegel, D. J., \& Silberman, J. (2008). Self-monitoring in clinical practice: a challenge for medical educators. Journal of Continuing Education in the Health Professions, 28(1), 5-13.

Fiorentino, L. H. (2012). Positive perspectives on the profession: Reframing through appreciative inquiry. Quest, 64(4), 209-228.

Grant, L., \& Kinman, G. (2012). Enhancing wellbeing in social work students: Building resilience in the next generation. Social Work Education, 31(5), 605-621.

Lucado, M. (2005). Cure for the common life: Living in your sweet spot. Nashville, Tennessee: W Publishing Group, a Division of Thomas Nelson.

Magruder Watkins, J., Mohr, B., J., \& Kelly, R. (2011). Appreciative Inquiry: Change at the speed of imagination, 2nd ed., San Francisco, Pfeiffer.

Ortberg, J. (2002). The life you've always wanted: Spritual disciplines for ordinary people (Expanded ed.). Grand Rapids, Michigan: Zondervan.

Phillips, J. (2012). The New Zealanders: European New Zealanders. Te Ara - The Encyclopedia of New Zealand. Retrieved 14th November 2013, from http: / / www.teara.govt.New Zealand / en / document/3561 / mrs-oaklands-story.

Sanchez, M., E. (2010). Globalisation and loss of identity. International Forum of Psychoanalysis, 19(2), 71-77.

Singer, J. B. (2010). So you want to work abroad? An interview with David Dininio [Episode 58]. Social Work Podcast, retrieved 10th March 2013 from http: / / socialworkpodcast.com/2010/04/ so-you-want-to-work-abroad-interview.html.

Te Wananga O Aotearoa. (2011). Mauri Ora: National Certificate in Maori (Te Waharoa). Information available online at http: / / www.openwananga.ac.New Zealand/index.php/our-programmes/mauri-ora.

Women's Division of the New Zealand Farmer's Union (WDNZFU). (1939). Brave days - pioneer women of New Zealand. Dunedin and Wellington: New Zealand, A. H. and A. W. Reed.

Your Choice. (2009). Messages from lessons for teenagers. Twickenham, England: Your Choice at the Crossway Pregnancy Crisis Centre. 